\title{
The Evaluation of Mechanical Properties of Concrete Due to The Use of Glass Waste as Partial Substitution of Fine Aggregate
}

\author{
(Evaluasi Sifat Mekanis Beton akibat Pengaruh Penggunaan Limbah Kaca sebagai Subtitusi \\ Sebagian Agregat Halus)
}

\author{
Gati Annisa Hayu*), Kharisma Dewi N., Aryawitra G., Rivaldo Akbar S. \\ Program Studi Teknik Sipil, Fakultas Perencanaan Infrastruktur, Universitas Pertamina \\ Jl. Teuku Nyak. Arief Jakarta 12220
}

\section{ABSTRACT}

Increasing human awareness of the importance of protecting the environment and conserving natural resources requires concrete innovation as an environmentally friendly and sustainable material. Accumulated of solid waste begins to be processed and reu sed, one of which is as a constituent of concrete. Among the various types of solid waste, glass waste is considered as an alternative that can be used as a substitute for fine aggregate (sand), coarse aggregate (split stone) and cement. This study investigated the use of mix coloured glass waste consisting of clear, green, and brown as partial substitution of sand in concrete. Although the glass colors were mixed, the proportion of each color had been determined in this study, namely 25\%, 25\%, and $50 \%$. The purpose of determining these proportions is to find out which type of color glass has the most effect on concrete mix. The target characteristic strength of $25 \mathrm{MPa}$ was produced by replacing sand with $20 \%$ of mix coloured waste glass. Three combinations of concrete mixes were prepared for this study. Compression tests were conducted at 7, 14, and 28 days. Workability of fresh concrete, density, compressive strength, and failure mode were investigated in this study. Results showed that the use of waste glass was able to increase the workability of fresh concrete. K1, K 2, and K3 obtained slump values which were 4\%, 6,7\%, and 1,3\% higher than normal concrete. Normal concrete and all combinations exhibited similar density values. Only normal concrete achieved the characteristic strength of $25,7 \mathrm{MPa}$ at 28 days. Meanwhile K1, K2, and K3 achieved strengths of 22,4 MPa, 22,1 MPa, and 24,7 MPa, respectively. It was evident that as workability values increased, the compressive strengths were noticed to reduce.

Meningkatnya kesadaran manusia akan pentingnya perlindungan terhadap lingkungan dan konservasi sumber daya alam, menuntut adanya inovasi beton sebagai material yang ramah lingkungan dan dapat digunakan secara berkelanjutan. Limbah padat yang menumpuk dan sulit terurai mulai diolah dan dimanfaatkan kembali, salah satunya sebagai bahan penyusun beton. Dari sekian macam limbah padat, limbah kaca merupakan alternatif yang dapat digunakan sebagai bahan subtitusi agregat halus (pasir), agregat kasar (batu), maupun semen. Penelitian ini membahas mengenai penggunaan limbah kaca mix coloured yang terdiri dari warna transparan, coklat, dan hijau sebagai subtitusi sebagian agregat halus pada beton. Meskipun warna kaca yang digunakan dicampur, akan tetapi proporsi dari masing-masing warna menjadi fokus pada penelitian ini. Kuat rencana beton adalah $25 \mathrm{MPa}$ dan proporsi kaca mix coloured yang digunakan adalah 20\% dari berat pasir. Dalam menentukan 20\% kaca mix coloured, digunakan 3 kombinasi pencampuran warna kaca. Pada setiap kombinasi telah ditentukan proporsi dari masing-masing warna limbah kaca, yaitu 25\%, 25\%, dan 50\%. Tujuan dari penentuan proporsi ini adalah untuk mengetahui jenis kaca manakah yang paling berpengaruh pada campuran beton. Pengujian dilakukan pada hari ke 7, 14, dan 28. Hasil yang akan dibahas pada penelitian ini meliputi kemampuan alir (workability) beton segar, massa jenis beton, kuat tekan beton, dan pola kerusakan beton. Hasil penelitian menunjukkan bahwa penggunaan kaca mampu meningkatkan workability beton. Persentase peningkatan workability antara K1, K2, dan K3 terhadap beton normal $(\mathrm{N})$ adalah 4\%, 6,7\%, dan 1,3\%. Massa jenis beton normal $(\mathrm{N})$ dan beton inovasi memiliki nilai yang berdekatan. Kuat tekan beton tertinggi dicapai oleh beton normal (N), sebesar 25,7 MPa. Kuat tekan beton K1, K2, dan K3 masing-masing sebesar 22,4 MPa, 22,1 Mpa, dan 24,7 MPa. Ini menunjukkan bahwa workability berbanding terbalik dengan kuat tekan beton.

Keywords: Concrete Innovation, Fracture Mode, Glass Waste, Mechanical Properties, Workability. 


\section{PENDAHULUAN}

Sektor konstruksi mengalami peningkatan permintaan penggunaan beton akibat pesatnya perkembangan infrastruktur. Tingginya permintaan penggunaan beton sebagai material konstruksi tentu saja akan meningkatkan proses produksi beton yang dapat memicu eksplorasi sumber daya alam seperti pasir alam dan batu alam [1]. Eksplorasi sumber daya alam ini dapat terjadi karena beton merupakan material komposit yang sekitar $75 \%$ bahan baku penyusunnya adalah agregat halus (pasir) dan agregat kasar (batu). Persentase yang besar ini menyebabkan pasir maupun batu memiliki peranan penting dalam menentukan sifat mekanis beton [2]. Permasalahan mulai muncul ketika beton yang semula dianggap sebagai material yang mudah diproduksi karena ketersediaan bahan bakunya, saat ini justru dihadapkan pada potensi bahaya eksplorasi berlebih agregat penyususnnya yang mengancam keseimbangan lingkungan. Menurut Badan Pusat Statistik Indonesia [3], pada tahun 2019 perusahaan penambang pasir di Indonesia mencapai 63.112 unit dan ini belum termasuk penambang lokal serta illegal.

Meningkatnya kesadaran manusia akan pentingnya perlindungan terhadap lingkungan dan konservasi sumber daya alam, menuntut adanya inovasi beton sebagai material yang ramah lingkungan dan dapat digunakan secara berkelanjutan. Limbah padat yang menumpuk dan sulit terurai mulai diolah dan dimanfaatkan kembali, salah satunya sebagai bahan penyusun beton. Berdasarkan beberapa penelitian terdahulu, diketahui bahwa pemanfaatan limbah padat ini dianggap sebagai alternatif yang dapat dilakukan untuk melindungi lingkungan, mengonversi sumber daya alam, namun dapat meningkatkan sifat mekanis beton [4]. Dari sekian macam limbah padat, limbah kaca merupakan alternatif yang dapat digunakan sebagai bahan subtitusi agregat halus (pasir), agregat kasar (batu), maupun semen. Di Indonesia sendiri, limbah kaca menempati urutan ketujuh penyumbang sampah terbesar dengan sifat yang sulit terurai.

Menurut Topcu dan Canbaz [5], limbah kaca dapat digunakan sebagai bahan pengganti agregat halus dilihat dari sifat fisik dan komposisi kimianya. Berdasarkan sifat fisiknya, limbah kaca merupakan bahan yang mempunyai permukaan transparan, aman, tahan abrasi dan tahan lama. Sedangkan dari segi kompoisis kimianya, kandungan pada limbah kaca menyerupai kandungan pada pasir. Hal serupa juga dinyatakan oleh Andilolo, dkk [6], kaca memiliki kandungan $\mathrm{SiO}_{2}$ lebih dari $70 \%$ dan kandungan lain berupa $\mathrm{Na}_{2} \mathrm{O}$ dan $\mathrm{CaO}$. Tabel 1 menunjukkan perbandingan komposisi kimia antara kaca dan pasir alam.

Studi mengenai limbah kaca sebagai bahan penyusun beton telah banyak dilakukan dan masih terus dikembangakan [1], [4], [7] - [12]. Dalam studi tersebut digunakan limbah kaca sebagai bahan pengganti pasir, batu, ataupun semen. Parameter yang digunakan berkisar pada pengaruh warna limbah kaca baik dicampur (mixed colour glass) ataupun dipisah (transparan, coklat, dan hijau), ukuran butir limbah kaca, dan komposisi kimianya. Akan tetapi jika dilihat dari hasil penelitian tersebut masih ditemukan ketidakkonsistenan. Hal ini dipengaruhi oleh sumber/asal produksi kaca, karakteristik kaca, tipe kaca, dan juga proses manufaktur yang dialami oleh kaca itu sendiri.

Penelitian ini membahas mengenai penggunaan limbah kaca mix coloured yang terdiri dari warna transparan, coklat, dan hijau sebagai subtitusi sebagian agregat halus pada beton. Meskipun warna kaca yang digunakan dicampur, akan tetapi proporsi dari masingmasing warna menjadi fokus pada penelitian ini. Limbah kaca pada penelitian ini diperoleh dari daerah Kutorejo, Pandaan, Kabupaten Pasuruan, Jawa Timur. Kuat rencana beton adalah $25 \mathrm{MPa}$ dan proporsi kaca yang digunakan adalah 20\% dari berat pasir. Pemilihan proporsi ini merujuk pada penelitian yang telah dilakukan oleh Iqbal dan Hayu [13]. Hasil yang akan dibahas pada penelitian ini meliputi kemampuan alir (workability) beton segar, berat jenis beton, kuat tekan beton, dan pola kerusakan beton. Penelitian ini bertujuan untuk mendukung pengembangan inovasi material beton yang ramah lingkungan dan berkelanjutan dengan memanfaatkan limbah kaca sebagai bahan pengganti. 
Tabel 1. Perbandingan Komposisi Kimia Kaca dan Pasir [7]

\begin{tabular}{ccccc}
\hline Komposisi (\%) & Kaca Transparan & Kaca Coklat & Kaca Hijau & Pasir Alam \\
\hline $\mathrm{SiO}_{2}$ & 72,14 & 72,08 & 71,22 & 88,54 \\
$\mathrm{Al}_{2} \mathrm{O}_{3}$ & 1,56 & 2,19 & 1,63 & 1,21 \\
$\mathrm{Fe}_{2} \mathrm{O}_{3}$ & 0,006 & 0,22 & 0,32 & 0,76 \\
$\mathrm{CaO}$ & 10,93 & 10,45 & 10,79 & 5,33 \\
$\mathrm{MgO}$ & 1,48 & 0,72 & 1,57 & 0,42 \\
$\mathrm{Na} 2$ & 13,04 & 13,71 & 13,12 & 0,33 \\
$\mathrm{~K}_{2} \mathrm{O}$ & 0,62 & 0,16 & 0,64 & 0,31 \\
$\mathrm{TiO}_{2}$ & 0,05 & 0,1 & 0,07 & 0,05 \\
$\mathrm{Cr}_{2} \mathrm{O}_{3}$ & - & 0,01 & 0,22 & - \\
\hline
\end{tabular}

\section{Prosedur Penelitian}

\section{Material}

Penelitian ini menggunakan semen Portland Tipe 1, agregat kasar berupa batu split, dan agregat halus berupa pasir bangka. Ukuran maksimum agregat kasar yang digunakan adalah $2,5 \mathrm{~cm}$ sementara pasir bangka yang digunakan adalah pasir lolos ayakan $4,75 \mathrm{~mm}$.

Limbah kaca yang digunakan diperoleh dari daerah Kutorejo dengan tiga macam warna yang terpisah, yaitu: transparan $(\mathrm{T})$, coklat $(\mathrm{C})$, dan hijau $(\mathrm{H})$. Dalam penelitian ini limbah kaca yang digunakan sebagai subtitusi pasir sebesar 20\% adalah campuran ketiga warna yang ada (mix coloured) namun dengan proporsi yang sudah ditentukan. Terdapat tiga kombinasi campuran warna kaca yang digunakan, yaitu: K1, K2, dan K3. Sebagai contoh, K1 adalah kombinasi limbah kaca mix coloured yang terdiri dari 50\% kaca transparan, $25 \%$ kaca hijau, dan 25\% kaca coklat. Kombinasi lainnya dan juga jumlah sampel beton ditunjukkan pada Tabel 2. Selain tiga kombinasi campuran warna kaca, dalam penelitian ini juga dibuat beton normal (N) tanpa subtitusi yang digunakan sebagai kontrol. Limbah kaca yang diperoleh dihancurkan dengan crusher agar menjadi partikel yang lebih halus untuk kemudian diayak menggunakan sieve shaker. Serbuk limbah kaca (SLK) yang lolos ayakan 4,75 mm digunakan sebagai subtitusi sebagian pasir.

Tabel 2. Variasi dan Proposri Limbah Kaca

\begin{tabular}{|c|c|c|c|c|c|c|c|c|c|c|}
\hline Kode & \multirow{4}{*}{$\mathrm{N}$} & \multicolumn{3}{|c|}{ K1 } & \multicolumn{3}{|c|}{$\mathrm{K} 2$} & \multicolumn{3}{|c|}{ K3 } \\
\hline Warna Kaca & & $\mathrm{T}$ & $\mathrm{H}$ & $\mathrm{C}$ & $\mathrm{T}$ & $\mathrm{H}$ & $\mathrm{C}$ & $\mathrm{T}$ & $\mathrm{H}$ & $\mathrm{C}$ \\
\hline $\begin{array}{c}\text { Proporsi Kaca Mix } \\
\text { Coloured }\end{array}$ & & \multicolumn{3}{|c|}{$20 \%$} & \multicolumn{3}{|c|}{$20 \%$} & \multicolumn{3}{|c|}{$20 \%$} \\
\hline $\begin{array}{c}\text { Proporsi Tiap } \\
\text { Warna Kaca }\end{array}$ & & $50 \%$ & $25 \%$ & $25 \%$ & $25 \%$ & $50 \%$ & $25 \%$ & $25 \%$ & $25 \%$ & $50 \%$ \\
\hline \multirow{3}{*}{$\begin{array}{c}\text { Jumlah Sampel } \\
\text { Beton }\end{array}$} & 3 & \multicolumn{3}{|c|}{3} & \multicolumn{3}{|c|}{3} & \multicolumn{3}{|c|}{3} \\
\hline & 3 & \multicolumn{3}{|c|}{3} & \multicolumn{3}{|c|}{3} & \multicolumn{3}{|c|}{3} \\
\hline & 3 & \multicolumn{3}{|c|}{3} & \multicolumn{3}{|c|}{3} & \multicolumn{3}{|c|}{3} \\
\hline Total & \multicolumn{10}{|c|}{36} \\
\hline
\end{tabular}




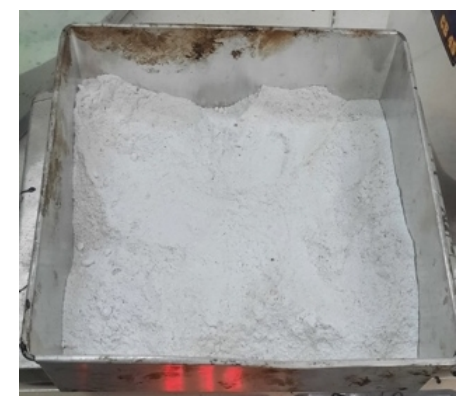

(a)

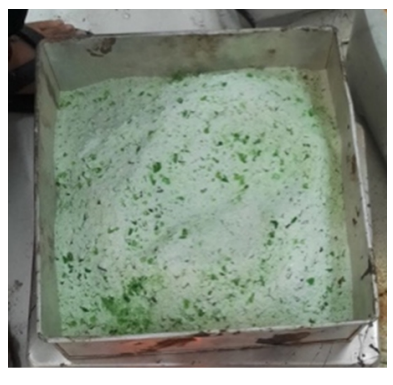

(b)

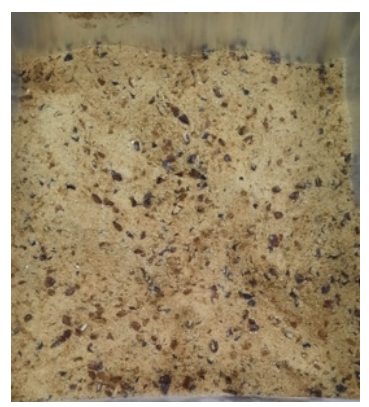

(c)

Gambar 1. Serbuk Limbah Kaca (a) Transparan (b) Hijau (c) Coklat

\section{Mix Design}

Mix Design yang digunakan dalam penelitian ini berdasarkan ACI Committee 211. Kuat tekan rencana beton hari ke-28 adalah $25 \mathrm{MPa}$ dengan benda uji silinder ukuran $15 \times 30 \mathrm{~cm}$. Target nilai slump adalah $7,5-10 \mathrm{~cm}$. Berdasarkan hasil perhitungan diperoleh nilai $\mathrm{W} / \mathrm{C}$ ratio sebesar 0,568 .

SLK yang sudah tercampur dituangkan ke dalam concrete mixer ketika proses pengadukan agar adonan beton lebih homogen. Pemampatan beton segar dilakukan dengan memukul cetakan beton untuk memastikan tidak ada rongga udara dan selanjutnya dibiarkan selama 24 jam untuk proses pengerasan. Setelah 24 jam, beton yang telah mengeras dikeluarkan dari cetakan dan dilakukan curing sesuai dengan periode pengetesan. Proporsi Mix Design untuk 1 silinder diperlihatkan pada Tabel 3.

\section{METODE PENELITIAN}

Studi penelitian meliputi: (i) pengujian karaktersitik bahan penyusun (berat jenis, kadar air, specific gravity, penyerapan agregat, kadar lumpur), (ii) slump test dan massa jenis beton, dan (iii) kuat tekan dan pola kerusakan beton.

Tabel 3. Proporsi Mix Design untuk 1 Silinder

\begin{tabular}{cccc}
\hline $\begin{array}{c}\text { Bahan } \\
\text { Penyusun }\end{array}$ & $\mathrm{K} 1(\mathrm{Kg})$ & $\mathrm{K} 2(\mathrm{Kg})$ & $\mathrm{K} 3(\mathrm{Kg})$ \\
\hline Semen & 1,803 & 1,803 & 1,803 \\
Air & 0,871 & 0,871 & 0,871 \\
Batu Split & 5,363 & 5,363 & 5,363 \\
Pasir & 3,533 & 3,533 & 3,533 \\
Transparan & 0,442 & 0,221 & 0,221 \\
Coklat & 0,221 & 0,221 & 0,442 \\
Hijau & 0,221 & 0,442 & 0,221 \\
\hline
\end{tabular}

Pengujian sifat bahan penyusun beton dalam hal ini agregat halus, agregat kasar, dan SLK dilakukan berdasarkan beberapa standar ASTM (ditunjukkan pada Tabel 4). Pengujian slump test dilakukan pada beton segar berdasarkan ASTM C143. Pengujian tekan beton dilakukan pada seluruh sampel yang telah dibuat, dimana setiap variasi dan setiap usia pengetesan terdapat 3 buah sampel beton. Setelah tes tekan beton, pengamatan terhadap pola kerusakan beton dilakukan dengan menggunakan tiga unit kamera untuk mengamati beberapa sisi beton. Pengamatan pola kerusakan beton didasarkan pada ASTM C39/C39M-05. Berdasarkan ASTM C39/C39M-05 terdapat 5 jenis pola kerusakan, yaitu: pola kerusakan cone, cone and split, cone and shear, shear, dan columnar.

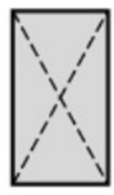

(1) Cone

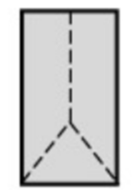

(2)

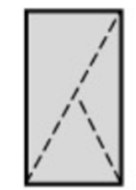

(3) Cone and Split Cone and Shear

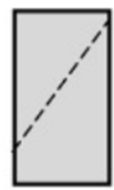

(4)

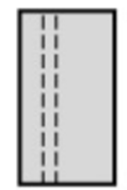

(5)
Gambar 2. Pola Kerusakan pada Benda Uji Silinder [16].

\section{HASIL DAN PEMBAHASAN}

\section{Sifat Bahan Penyusun Beton}

Tabel 4 menunjukkan hasil pengujian sifat/karakter bahan penyusun beton dan standar ASTM yang digunakan. Dapat diketahui bahwa berat jenis agregat kasar belum memenuhi range nilai yang ditetapkan, yaitu $1,6-1,9 \mathrm{~g} / \mathrm{cm}^{3}$. Selain itu kadar air agregat kasar juga masih dibawah standard yang seharusnya, yaitu $2 \%$. 
Tabel 4. Jenis Pengujian dan Standard

\begin{tabular}{cccccc}
\hline Pengujian & Nilai & Standar ASTM & Pengujian & Nilai & Standar ASTM \\
\hline Berat jenis agregat halus & $1,572 \mathrm{~g} / \mathrm{cm}^{3}$ & C29 & Kadar air agregat kasar & $1,607 \%$ & C566 \\
Berat jenis agregat kasar & $1,469 \mathrm{~g} / \mathrm{cm}^{3}$ & C29 & Specific gravity agregat halus & 2,538 & C128 \\
Berat Jenis K1 & $1,691 \mathrm{~g} / \mathrm{cm}^{3}$ & C29 & Specific gravity agregat kasar & 2,638 & C127 \\
Berat Jenis K2 & $1,714 \mathrm{~g} / \mathrm{cm}^{3}$ & C29 & Penyerapan agregat halus & $1,419 \%$ & C128 \\
Berat jenis K3 & $1,752 \mathrm{~g} / \mathrm{cm}^{3}$ & C29 & Penyerapan agregat kasar & $1,99 \%$ & C127 \\
Kadar air agregat halus & $2,839 \%$ & C566 & Kadar lumpur agregat halus & $0,286 \%$ & C117 \\
\hline
\end{tabular}

Gambar 3 menunjukkan hasil analisis distribusi ukuran agregat halus dan SLK berdasarkan ASTM C136-01. Terlihat bahwa distribusi agregat halus maupun SLK masuk dalam kategori well graded. Persentase lolos saringan kumulatif agrregat halus masih berada dalam range batas bawah dan batas atas.
Namun demikian SLK memiliki partikel yang lebih halus dibandingkan agregat halus. Pada gambar tersebut terlihat bahwa SLK mendominasi persentase lolos saringan kumulatif pada ayakan 1,18 mm hingga $0,075 \mathrm{~mm}$.

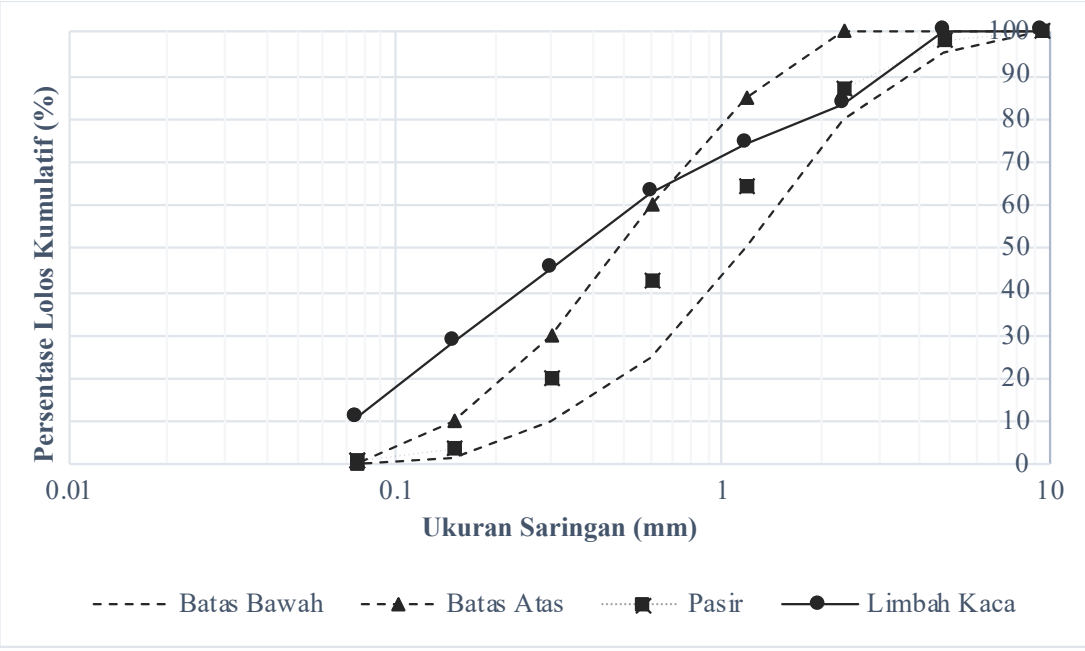

Gambar 3. Kurva Distribusi Ukuran Agregat

\section{Slump Test}

Tabel 5. Slump Test dan Massa Jenis Beton

\begin{tabular}{ccc}
\hline Jenis Beton & Slump $(\mathrm{mm})$ & Massa Jenis $\left(\mathrm{gr} / \mathrm{cm}^{3}\right)$ \\
$\mathrm{N}$ & 75 & 2,337 \\
$\mathrm{~K} 1$ & 78 & 2,264 \\
$\mathrm{~K} 2$ & 80 & 2,270 \\
$\mathrm{~K} 3$ & 76 & 2,287 \\
\hline
\end{tabular}

Berdasarkan Tabel 5, nilai slump untuk keempat jenis beton masih sesuai batasan slump yang direncanakan,yaitu 75-100 mm. Namun demikian dapat dilihat bahwa subtitusi SLK membuat nilai slump lebih tinggi dibandingkan dengan beton normal. Ini mengindikasikan bahwa subtitusi SLK sebesar 20\% meningkatkan workability beton. Hal ini disebabkan karena kaca memiliki kemampuan penyerapan air yang rendah [14] atau zero water absorption.
Hasil yang berbeda ditunjukkan oleh penelitian [7] dan [15]. Menurut penelitian tersebut penambahan SLK justru menurunkan nilai slump akibat ketajaman ujung kaca dan bentuk yang lebih bersudut sehingga menghalangi pergerakan dari pasta semen dan partikel penyusun beton. Namun demikian, hal ini terjadi karena pada penelitian tersebut ukuran partikel SLK lebih kasar dibandingkan dengan agregat halusnya. Sementara pada penelitian ini, ukuran SLK yang digunakan lebih halus dibandingkan agregat halusnya.

Massa Jenis

Tabel 5 memperlihatkan perbandingan massa jenis antar keempat jenis beton. Beton normal $(\mathrm{N})$ memiliki density sebesar 2,2337 $\mathrm{gr} / \mathrm{cm}^{3}$, sementara beton $\mathrm{K} 1$, $\mathrm{K} 2$, dan K3 masing-masing memiliki nilai 2,264 $\mathrm{gr} / \mathrm{cm}^{3}, 2,270 \mathrm{gr} / \mathrm{cm}^{3}, 2,287 \mathrm{gr} / \mathrm{cm}^{3}$. Massa jenis beton dengan SLK memiliki nilai yang mendekati massa jenis beton normal. Massa jenis terbesar adalah 
beton $\mathrm{K} 3$, disusul oleh $\mathrm{K} 2$ dan K1. Ini selaras dengan hasil pengujian berat jenis dari ketiga kombinasi ini.

Kuat Tekan

Uji kuat tekan dilakukan pada beton dengan 3 kombinasi dan dibandingkan dengan beton normal sebagai kontrol. Kuat tekan tertinggi hari ke-7 terjadi pada beton normal $(\mathrm{N})$. K1, K2, dan K3 mencapai kekuatan sebesar 85\%, 91\%, dan 93\% jika dibandingkan dengan beton normal $(\mathrm{N})$.
Kuat tekan tertinggi pada hari ke-14 terjadi pada beton normal $(\mathrm{N})$ yakni sebesar $21 \mathrm{MPa}$. Sementara $\mathrm{K} 1$, K2, dan K3 mencapai kekuatan sebesar 85\%, $86 \%$, dan 99\% jika dibandingkan dengan beton normal (N). Dapat dilihat disini bahwa kecenderungan kekuatan pada hari ke-7 sama dengan hari ke-14. K1 yang didominasi oleh SLK transparan memberikan efek penurunan kekuatan yang paling tinggi.

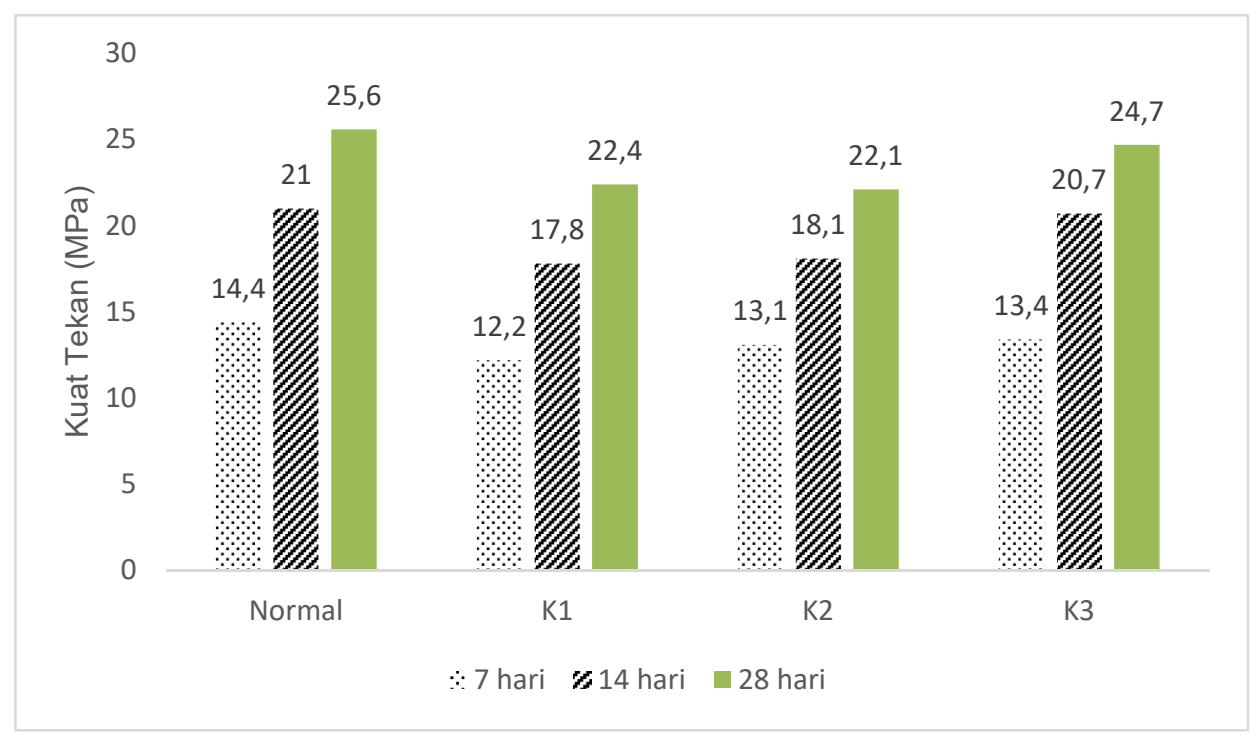

Gambar 4. Perbandingan Kuat Tekan

Hasil yang sama juga ditunjukkan pada uji kuat tekan hari ke-7 pada penelitian [7]. Kuat tekan beton dengan subtitusi SLK transparan mempunyai nilai terendah dibandingkan dengan beton normal $(\mathrm{N})$ dan SLK hijau ataupun coklat. Dalam penelitian tersebut juga dilakukan pengecekan terhadap kandungan udara pada mortar. Hasil menunjukkan bahwa mortar dengan subtitusi SLK transparan mempunyai air content yang paling tinggi dibandingkan mortar SLK lainnya. Selain itu, dari pengujian hasil SEM pada penelitian tersebut diperoleh hasil bahwa terdapat micro-crack pada partikel kaca transparan. Hal ini bisa menjadi penyebab mengapa kuat tekan beton dengan SLK menujukkan hasil yang paling rendah.

Jika melihat kuat tekan hari ke-28, dapat diketahui bahwa hanya beton normal $(\mathrm{N})$ saja yang mencapai kuat tekan beton rencana. Namun demikian, K3 mencapai kekuatan tekan sebesar 96\% dibandingkan dengan beton normal (N). Jika merujuk pada penelitian [7], kandungan udara pada mortar dengan SLK coklat adalah yang paling rendah. Selain itu, dari hasil uji SEM diketahui bahwa tidak terdapat microcrack pada partikel kaca coklat.

Faktor lain yang menyebabkan ketidaktercapaian kuat tekan beton dengan subtitusi SLK adalah pengujian agregat kasar (berat jenis dan kadar air) yang belum memenuhi syarat ASTM. Tidak tercapainya nilai berat jenis agregat kasar berdampak pada stabilitas volume dan kuat tekan beton. Ukuran partikel SLK yang lebih halus membuat ikatan pada Interfacial Transition Zone menjadi lebih lemah sehingga mereduksi ikatan antara partikel kaca dengan pasta semen.

Alkali-Silica Reaction (ASR) adalah faktor penting yang perlu diperhatikan dalam subtitusi SLK pada beton. ASR adalah reaksi yang terjadi antara silika yang terkandung pada kaca dengan alkali yang terkandung pada semen. Reaksi ini nantinya akan membentuk suatu gel ASR. Gel ASR menyerap air dan mengalami swell di bagian dalam mikrostruktur beton sehingga mengakibatkan munculnya tegangan internal yang dapat menurunkan kekuatan tekan beton. 


\section{Pola Kerusakan}

Pengujian pola kerusakan dilakukan pada beton usia 7, 14, dan 28 hari. Namun dalam penelitian ini akan ditampilkan perbandingan pola kerusakan untuk hari ke-28 saja.

Berdasarkan Gambar 8, pola kerusakan yang terjadi pada beton normal $(\mathrm{N})$ adalah jenis shear. Kekuatan tekan beton normal $(\mathrm{N})$ bisa mencapai nilai ultimatenya. Salah satu sampel beton K3 memiliki pola kerusakan shear namun juga mengalami pengelupasan pada permukaan atas.
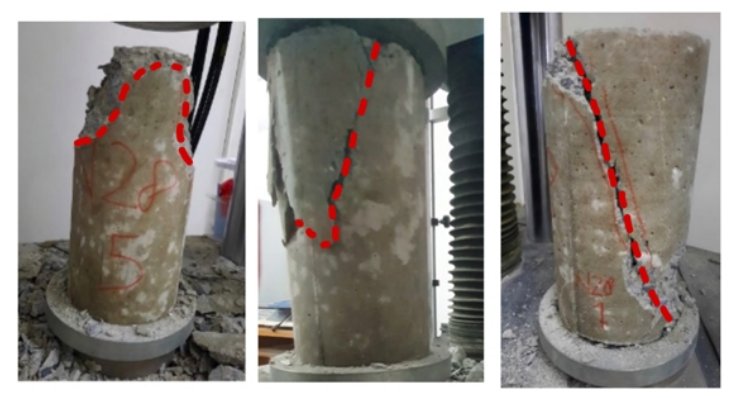

Gambar 5. Pola Kerusakan Beton Normal (N)
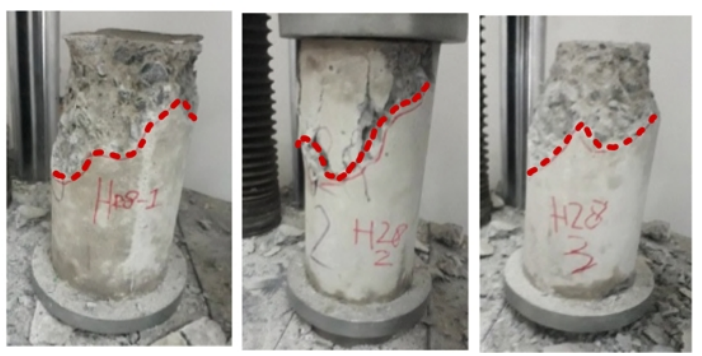

Gambar 7. Pola Kerusakan K2

K1 dan K2 mengalami pengelupasan pada bagian atas pada seluruh sampel beton yang diuji. Ini mengindikasikan bahwa ikatan antara pasta semen dan agregat pada dua kombinasi ini lebih lemah dibandingkan dengan beton normal $(\mathrm{N})$ dan K3. Ini selaras dengan hasil kuat tekan beton pada K1 dan K2 yang lebih kecil.

\section{KESIMPULAN}

Beberapa kesimpulan yang dapat diperoleh dari penelitian ini adalah subtitusi pasir dengan serbuk limbah kaca sebesar 20\% menyebabkan peningkatan
Pengelupasan ini menunjukkan bahwa beton tidak mampu mendistribusikan beban yang diterimanya ke seluruh beton, sehingga hanya bagian atas saja yang rusak. Namun demikian pada dua sampel lainnya terlihat adanya pengelupasan di area atas. Hal ini disebabkan karena pembebanan tekan diberikan pada sisi atas beton. Pengelupasan area ini terjadi karena hilangnya atau lemahnya ikatan antara pasta semen dengan agregat kasar dan agregat halus (pasir dan SLK). Lemahnya ikatan pasta semen dan agregat menyebabkan kuat tekan beton tidak dapat mencapai nilai ultimate-nya.
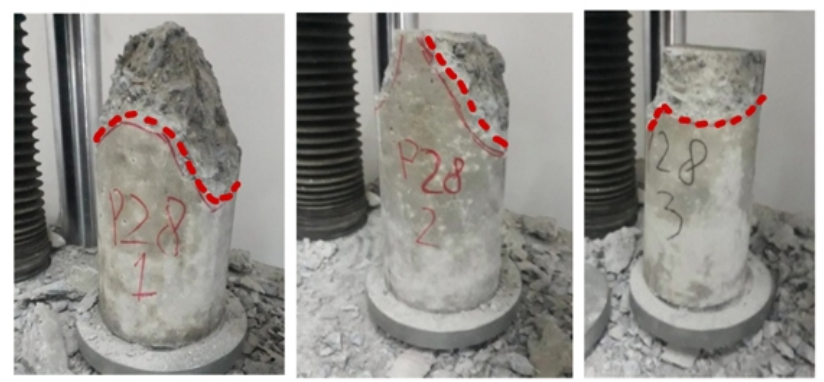

Gambar 6. Pola Kerusakan K1
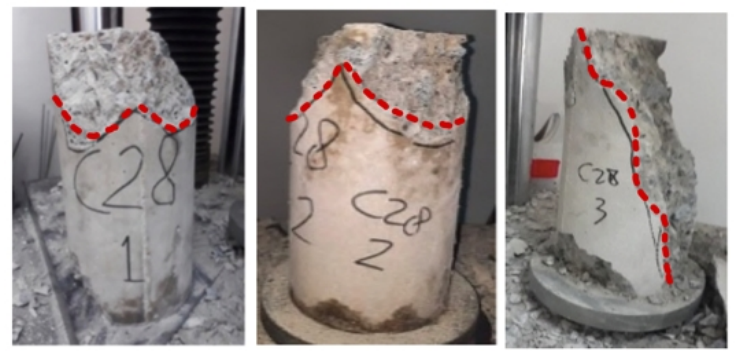

Gambar 8. Pola Kerusakan K3

workability beton namun masih memenuhi target nilai slump. Kombinasi limbah kaca mix coloured yang terdiri dari 25\% kaca transparan, 25\% kaca hijau, dan 50\% kaca coklat menghasilkan nilai workability paling rendah. Massa jenis beton normal $(\mathrm{N})$ memiliki nilai yang berdekatan dengan tiga kombinasi beton. Ini menunjukkan bahwa subtitusi pasir dengan serbuk limbah kaca sebesar 20\% tidak menyebabkan perubahan massa jenis beton yang berarti. Kuat tekan beton tertinggi dihasilkan oleh beton normal $(\mathrm{N})$, yaitu sebesar 25,6 $\mathrm{MPa}$. Beton dengan subtitusi serbuk limbah kaca gagal mencapai kuat tekan rencana. Kombinasi limbah kaca mix coloured yang terdiri dari $25 \%$ kaca transparan, 25\% kaca hijau, dan 50\% kaca 
coklat menghasilkan kuat tekan beton tertinggi sebesar 24,7 $\mathrm{MPa}$ dibandingan dengan kombinasi lainnya. Kombinasi limbah kaca mix coloured yang terdiri dari 50\% kaca transparan, 25\% kaca hijau, dan $25 \%$ hanya mampu mencapai kuat tekan sebesar 22,4 MPa. Kombinasi limbah kaca mix coloured yang terdiri dari 25\% kaca transparan, 50\% kaca hijau, dan 25\% hanya mampu mencapai kuat tekan sebesar 22,1 MPa. Berat jenis agregat kasar dan kadar air agregat kasar yang tidak memenuhi standar ASTM menjadi salah satu penyebab mengapa kuat tekan beton dengan serbuk limbah kaca tidak mencapai target. Selain itu, butiran serbuk limbah kaca yang lebih halus dibandingkan dengan pasir juga menjadi penyebab kegagalan ini. Beton normal (N) memiliki pola kerusakan shear atau diagonal. Kerusakan jenis ini memungkinkan beton mencapai kuat ultimatenya karena beban tekan tersebar di seluruh beton. Subtitusi pasir dengan serbuk limbah kaca sebesar 20\% memperlemah ikatan antara pasta semen dengan agregat. Hal ini ditunjukkan dengan terjadinya pengelupasan pada area dekat pembebanan pada sampel beton yang mengandung serbuk limbah kaca.

Hal yang dapat disarankan pada penelitan ini demi kesempurnaan penelitian selanjutnya adalah pemanfaatan limbah kaca dengan partikel yang lebih kasar untuk mengetahui perngaruhnya pada beton. Selain itu, penyelidikan mengenai Alkali-Silica Reaction (ASR) perlu dilakukan untuk mengetahui durabilitas beton.

\section{DAFTAR PUSTAKA}

[1] N. Tamanna, R. Tuladhar, and N. Siyakugan, "Performance of Recylced Waste Glass Sand as Partial Replacement of Sand in Concrete Performance of Recylced Waste Glass Sand as Partial Replacement of Sand in Concrete," Construction and Building Materials, 239, 117084, pp. 1-9, April 2020.

[2] A. Mohammadi, A. Ghiasvand, and M Nili, "Relation Between Mechanical Properties of Concrete and Alkali-Silica Reaction (ASR); a review," Construction and Building Materials, 258, 119567, pp. 1-16, June 2020.

[3] Badan Pusat Statistik Indonesia, Statistik Pertambangan Bahan Galian Indonesia 2019, BPS RI, Jakarta, 2019.

[4] H. Du and K.H. Tan, "Use of Waste Glass as Sand in Mortar: Part II - Alkali - Silica Reaction and Mitigation Methods," Cement \& Concrete Composites, 35, pp. 118-126, 2013.
[5] I.B. Topcu and E.M. Canbaz, "Properties of Concrete Containing Waste Glass," Cement \& Concrete Research, 34 (2), pp. $267-274,2014$.

[6] J. Andilolo, D.P. Ambali, and M.L. Paembonan, "Karakterisasi Serbuk Kaca sebgai Subtitusi Parsial Semen terhadap sifat Fisis-Mekanis Campuran Beton," Dynamic SainT, pp. 850-854, 2019.

[7] K.H. Tan and H. Du, "Use of Waste Glass as Sand in Mortar: Part I - Fresh, Mechanical and Durability Properties," Cement \& Concrete Composites 35, pp. 109$117,2013$.

[8] Z.Z. Ismail and E.A. Al-Hashmi, "Recycling of Waste Glass as a Partial Replacement for Fine Aggregate in Concrete," Waste Management 29, pp. 655 - 659, 2019.

[9] F.P. Cota, C.C.D. Melo, T.H. Panzera, A.G. Araujo, P.H.R. Borges, and F. Scarpa, "Mechanical Properties and ASR Evaluation of Concrete Tiles with Waste Glass Aggregate," Sustainable Cities and Society, 2015.

[10] S. Yang, J. Lu, and C.S. Poon, "Recycling of Waste Glass in Dry-Mixed Concrete Blocks: Evaluation of Alcali-Silica Reaction (ASR) by Accelerated Laboratory Tests and Long-Term Field Monitoring," Construction and Building Materials, 262, 120865, 2020.

[11] J.J. Sudjati, T. Yuliyanti, and Rikardus, "Pengaruh Penggunaan Serbuk Kaca sebagai Bahan Subtitusi Agregat Halus terhadap Sifat Mekanik Beton," Jurnal Teknik Sipil, Vol. 13, No. 1, 1-11, 2014.

[12] Kosim and A. Hasan, "Pemanfaatan Serbuk Kaca sebagai Bahan Tambah Agregat Halus untuk Meningkatkan Kuat Tekan Beton, "Pilar Jurnal Teknik Sipil, Vol. 10, No. 2, 170 - 178, 2014.

[13] R.M. Iqbal and G.A Hayu, "Pemanfaatan Abu Sekam Padi 10\% dan Limbah Kaca sebagai Bahan Subtitusi pada Campuran Beton Mutu fc' 25 MPa," Jurnal Teknik. Sipil SONDIR, 4 (2), 6-15, 2020.

[14] I.B. Topc, A.R. Boga, and T. Bilir, “Alkali-Silica Reactions of Mortars Produced by Using Waste Glass as Fine Aggregate and Admixtures such as Fly Ash and $\mathrm{Li}_{2} \mathrm{CO}_{3}$," Waste Management, 28, 878-884, 2008.

[15] S. Mindess, J.F. Young, and D. Darwin, Concrete. New Jersey: Prentice Hall, 2013.

[16] A.J. Hamad,"Size and Shape Effect of Specimen on The Compressive Strength of HPLWFC Reinforced with Glass Fiber," Journal of King Sand University Engineering Sciences, 29 (4), pp. 373-380, 2017. 